\title{
Kant on Moral Sensibility and Moral Motivation
}

OWEN WARE*

Nobody can or ever will comprehend how the understanding should have a motivating power; it can admittedly judge, but to give this judgment power so that it becomes a motive able to impel the will to performance of an action-to understand this is the philosopher's stone.

-Lectures on Ethics (MPC, AA 27:I428).

\section{N T R O D U C T I O N}

IN CONTRAST TO HIS RATIONALIST predecessors, Kant argues that feeling plays a positive role in moral life. Yet the exact nature of this role is far from clear. As much as Kant repeats that moral motivation must proceed from a "feeling of respect" (Gefühl der Achtung), he maintains with equal insistence that to act out of respect for the law is simply to recognize its value and authority. In what way, then, is respect for the law a feeling? And what place does this feeling have-if any-in Kant's ethics?

Despite the large body of secondary literature devoted to this topic, the details of Kant's position still remain elusive. ${ }^{\mathrm{I}}$ In the Critique of Practical Reason ( I788), for example, Kant argues that our recognition of the moral law must elicit both painful and pleasurable feelings in us. It must be painful, he explains, insofar as

${ }^{\mathrm{I}}$ The current literature on this topic owes its momentum to two influential papers: Andrews Reath's "Kant's Theory of Moral Sensibility," published in Kant-Studien (and later revised for his collection of essays, Agency and Autonomy), and Richard McCarty's "Kantian Moral Motivation," published in this journal. Since then a number of important studies have appeared. See Allison, Freedom; McCarty, "Kant's Theory of Rational Agency," Kant's Theory of Action; Purviance, "Apriority of Moral Feeling"; Wood, Kant's Ethical Thought, Kantian Ethics; Herrera, "Moral Triebfeder"; Guevara, Moral Motivation; Stratton-Lake, Duty and Moral Worth; Walker, "Achtung in the Grundlegung"; Grenberg, "Kant's Theory of Action," "Reason and Sensibility"; Guyer, Freedom, Law, and Happiness, Kant's Response to Hume, "Moral Feeling"; Ameriks, "Problem of Moral Motivation"; Zinkin, "Dynamical Terms"; Herman, "Transforming Incentives"; Morrison, Pleasure in Moral Action; Engstrom, "Triebfeder"; Geiger, "Rational Feelings"; Wuerth, "Sense and Sensibility." For earlier studies, see Paton, Categorical Imperative; Beck, Commentary; MacBeath, "Kant on Moral Feeling"; Wolf, Autonomy of Reason; and Broadie and Pybus, "Concept of Respect."

* Owen Ware is Assistant Professor of Philosophy at Simon Fraser University.

Journal of the History of Philosophy, vol. 52, no. 4 (2014) 727-746

$[727]$ 
the moral law limits our egoistic tendencies of choice, but also pleasurable, insofar as we see that this limitation is self-imposed ( $K p V$, AA $5: 73 ; 5: 8 \mathrm{I})$. On reflection, though, it is unclear how these feelings could properly relate to our recognition of the moral law itself-in Kant's terms, they may be "pathological"—so it is unclear how they could serve to motivate us to act from duty. As we shall see, commentators have left this skeptical worry unresolved, either because they deny moral feeling plays an active role in moral motivation, or because they only consider that role from the standpoint of a "battle of forces" model.

My aim in this paper is to advance a novel reading of Kant's account, one that considers the concept of moral feeling from the agent's own point of view. ${ }^{2}$ The discussion divides into five sections. In $\S$ I, I begin with a sketch of Kant's early struggle with these issues, reviewing some of his essays, letters, and lectures from the I760s and I770s. In $\$ 2$, I explain in greater detail the skeptical worry just mentioned, what I call motivational effect skepticism. In $\S_{3}$, I turn to my central text, Chapter III of the second Critique, clarifying what Kant means by a "feeling" (in \$3.I), and then emphasizing the importance of his distinction between "selflove" (Eigenliebe) and "self-conceit" (Eigendünkel) (in \$3.2). In §4, I reconstruct Kant's account from Chapter III, showing how the negative and positive aspects of moral feeling relate to our recognition of the moral law. Lastly, in $\S 5$, I show how my reconstruction brings a new perspective to a long-standing dispute over intellectualist and affectivist accounts of moral motivation.

\section{B A G K R O UND: THE “PHILOSOPHER'S T TONE”}

While it may be an exaggeration to say Kant went through a sentimentalist phase, in the "Prize Essay" written in 1762 he does claim that our judgments of the good derive from more basic, unanalyzable feelings; and he praises Francis Hutcheson for "providing us with a starting point from which to develop some excellent observations" under the name 'moral feeling' ( $D G$, AA 2:300). Yet the essay ends on a tentative note. Kant says we do not yet know "whether it is merely the faculty of cognition, or whether it is feeling (the first inner ground of the faculty of desire) which decides its first principles" ( $D G, \mathrm{AA}$ 2:300).

Kant seems to lean toward a sentimentalist view in his Observations on the Feeling of the Beautiful and Sublime, written in 1763 , when he says that virtue arises from a "consciousness of a feeling that lives in every human breast," that is, "the feeling of the beauty and the dignity of human nature" (GSE, AA 2:217). But right before saying this he asserts that virtue must be based on "principles." This indecisiveness runs throughout his other writings of the period. ${ }^{3}$ The only place

\footnotetext{
${ }^{2}$ See footnotes II, 29, and 40 below for indications of where my reading differs from other accounts in the secondary literature.

${ }^{3}$ For example, in his "Announcement" to the lecture program he designed for the Winter Semester of $1765-66$, Kant writes, "The distinction between good and evil in actions, and the judgment of moral rightness, can be known, easily and accurately, by the human heart through what is called sentiment, and that without the elaborate necessity of proofs" (NEV, AA 2:3 I I). But this does not commit him to the view that sentiment grounds moral principles, only that the conclusions of such principles can be known "by the heart." This may not be that different from Kant's mature view that moral principles are implicit in common human reason.
} 
where Kant appears to entertain a strong sentimentalist view is in an unpublished note written sometime around I764-68: "The rules of morality proceed from a special, eponymous feeling, upon which the understanding is guided" (Refl, AA I9:93). But even this is unclear. Does he mean moral feeling grounds those rules, or that it simply guides their execution?

It is difficult to say how we should read these early writings. There are points of agreement between Kant's early and mature ethical views, although I think it is important to highlight the uncertainty of his thinking prior to 1785 . His praise of Hutcheson in the "Prize Essay," to take one example, does not clarify his agreement with the sentimentalists. Nor do the other remarks I have cited. My view is that during the I 760 o Kant saw himself building on the ideas of the British, rather than defending their views. He indicates as much in his "Announcement" to the lecture series of 1765-66, where he says that Shaftesbury, Hutcheson, and Hume have "penetrated furthest in the search for the fundamental principles of all morality," though their search is "incomplete and defective." There he promises to supply in his lectures what the sentimentalists lack: "precision and completeness" (NEV, AA 2:3 II).

However we read these remarks, it is evident that Kant changed his focus between the publication of the "Prize Essay" and the Inaugural Dissertation (I770).$^{4}$ In the latter work we do not hear any praise of the sentimentalists. Kant does not even mention Hutcheson (or Shaftesbury or Hume, for that matter), and his brief remark on the foundation of moral principles indicates a firm break from their thinking: "moral concepts," he writes in $\$ 7$, "are cognized not by experiencing them but by the pure understanding itself" (MSI, AA 2:395). Other reflections from the late 1760 s foreshadow Kant's emerging view that moral principles are grounded in reason, and that moral feeling is an effect of those principles, not their foundation. ${ }^{5}$

In a letter to Marcus Herz, dated toward the end of I773, Kant makes his new position more clear:

The highest ground of morality must not simply be inferred from the pleasant; it must itself be pleasing in the highest degree. For it is no mere speculative idea; it must have the power to move. Therefore, though the highest ground of morality is intellectual, it must nevertheless have a direct relation to the incentives [Triebfedern] ${ }^{6}$ of the will. (Br, AA IO:I45; modified $)^{7}$

${ }^{4}$ What brought about this shift? In his paper "Kant and Greek Ethics," Klaus Reich gives us the following date: When Kant read the Phaedo, the dialogue where Socrates famously denounces moral systems grounded in sense rather than reason, which Reich believes Kant must have read before embarking on the Dissertation. Reich speculates the Phaedo must have impressed Kant, not only because it criticized a sentimentalist leaning he may have felt at the time, but because Mendelssohn, in his introduction to the 1767 German translation, made a persuasive case that the Phaedo represents Plato's own thinking. This is an interesting suggestion, but for lack of space I cannot pursue it here.

5Also compare the following unpublished fragment dated from I772: "Moral feeling succeeds the moral concept, but does not produce it; all the less can it replace it, rather it presupposes it" (Refl, AA I9:I 50).

${ }^{6}$ None of the English translations of 'Triebfeder' are satisfying. Stephen Engstrom makes a good case for 'driving spring' ("Triebfeder," 92), but I will follow Mary Gregor in using 'incentive.'

${ }^{7}$ Kant makes a similar claim in an earlier note around $1769-70$. "The immediate good can be found only in freedom," he writes. "For, because freedom is a capacity for action, even if it does not please us, freedom is not dependent upon the condition of a private feeling; however, it always refers 
730 JOURNAL OF THE HISTORY OF PHILOSOPHY 52:4 OCTOBER 2OI 4

Kant would spend the next eleven years struggling to formulate this "direct relation." Although the details of his view changed, Kant never departed from his anti-sentimentalist thesis that moral feeling must follow from moral judgment. As he puts it, "When I judge by understanding that the action is morally good, I am still very far from doing this action of which I have so judged. But if this judgment moves me to do the action, that is the moral feeling" (MPC, AA 27:1428). The underlying puzzle is to explain how a principle of reason can relate to the will as an "incentive" (Triebfeder), that is, how it can move us to act without depending on ordinary feelings of pleasure and pain. For years this puzzle appeared to Kant as if under a veil of mystery, so much so that he is reported to have said, during lecture, that its solution would be the "philosopher's stone" (MPC, AA 27:I428).

\section{MORAL FEELING I N THE GROUNDWORK}

With the publication of the Groundwork for the Metaphysics of Morals (I785), Kant appears to have abandoned the idea that moral feeling is necessary for moral motivation. ${ }^{8}$ Now the topic of "action from duty" takes on central importance. In Groundwork I, for example, Kant argues that our actions possess moral worth only if they are performed for the sake of duty, and from this he concludes that moral action must arise from a maxim that has "respect" (Achtung) as its basis. Interestingly, Kant's argument for how respect functions as a "feeling" (Gefühl) is tucked away in a single footnote, and it is here that we find him briefly returning to the puzzle of the philosopher's stone.

In this footnote Kant begins by repeating a claim from his early writings, that moral feeling is an effect of our recognition of the moral law, not its ground. "Respect," he says, is "the effect of the law on the subject, not the cause of the law" (GMS, AA 4:40I; modified). Working this claim further, Kant says that respect is not a feeling "received by means of influence" but is rather "self-generated by means of a rational concept": it arises when we apprehend a worth that "infringes upon" our self-love (GMS, AA 4:40In; modified).${ }^{9}$ To this extent, "there is something that is regarded as an object neither of inclination nor of fear, though it has something analogous to both." Clarifying this remark, Kant adds,

The object of respect is therefore simply the law, and indeed the law that we impose upon ourselves and yet as necessary in itself. As a law we are subject to it without consulting self-love; as imposed upon us by ourselves it is nevertheless a result of our

only to that which pleases, so it has a relation to feeling and can have a universally valid relation to feeling in general" (Refl, AA I9:I03).

${ }^{8}$ Due to restrictions of space, I will not take my discussion of moral sensibility beyond the second Critique, although I think there are developments worth exploring in the Critique of the Power of Judgment (I790), Religion Within the Boundaries of Mere Reason (I793), and the Metaphysics of Morals (I797). For discussion of these later texts, see Paul Guyer, "Moral Feeling," and Jeanine Grenberg, "Reason and Sensibility."

'Werner Pluhar translates 'Abbruch tut' as 'impairs' for symmetry with the violence invoked by 'striking down' (Nierderschlagung). I prefer 'infringes upon,' but in \$4.2 I will say why the Nierderschlagung of self-conceit is best understood as a kind of disillusionment. The battle metaphor is limited, and potentially misleading. 
will; and in the first respect it has an analogy with fear, in the second with inclination.

$\left(\right.$ GMS, AA 4:40In) ${ }^{\text {IO }}$

While he is not entirely clear, Kant may be saying that one side of respect is like fear because we regard anything that opposes our self-love with displeasure. This feeling would be "pathological" (i.e. based in sensibility) because it would be relative to our inclinations. Yet this answer is incomplete, as we can see right away, because a pathological feeling - the pain of having our self-love infringed upon-cannot explain what moves us to act from duty. Such pain is not related internally to our recognition of the moral law.

To illustrate the problem, consider the following analogy. Suppose I am driving and feel the desire to speed, and suppose I see a police officer and decide to slow down. What can we say is motivating me in this scenario? From a prudential point of view, it may be that I would rather deny myself the pleasure of speeding than suffer the consequences of getting a ticket. In making this judgment, I will likely experience something like pain in having my desire thwarted, and for good reason: I am prevented from doing what I want. Notice, however, that my initial pain-like feeling is not related internally to my thought of wanting to avoid a traffic fine. Instead, I am motivated by a desire to avoid what I judge will be the greater displeasure of getting the fine, relative to the momentary pleasure of indulging my desire. Thus, the pain I feel in having to restrain my impulse cannot serve as my incentive to act (namely, to slow down) because it comes after I have already made up my mind. Such pain comes too late, we might say, to explain the structure of prudential motivation.

Generalizing from this example, we can now ask whether our recognition of the moral law is only ever like this—-whether it only ever affects a pain-like feeling when we restrain our egoistic tendencies of choice. If so, it is unclear how the felt aspect of respect, even if in some sense necessary, could play a positive role in moral motivation. ${ }^{\text {II }}$ Admittedly, in the footnote from GMS, AA 4:40I, Kant also says that respect has an analogy with inclination: it is a pleasurable feeling we have when we discover the moral law is "imposed upon us by ourselves" and hence "a result of our will." But this remark only serves to invite the same question: How can a pleasurable feeling relate internally to our recognition of the moral law? The general concern here is not whether reason can have an effect on sensibility,

${ }^{10}$ Kant contrasts the feeling of fear with an inclination; but as Herbert Paton observes, an inclination is not a feeling (Categorical Imperative, 64). When discussing the "matter" of the faculty of desire in the second Critique, Kant speaks of "objects of inclination, whether of hope or fear" (KpV, AA 5:74). I believe this distinction is more consistent with Kant's view in the Groundwork: hope refers to an object of pleasure, fear to an object of pain.

${ }^{\mathrm{I}}$ Versions of this problem are voiced by Hegel (Phänomenologie), Schiller (Anmut und Würde), and Dieter Henrich ("Ethics of Autonomy"). To the best of my knowledge, Lewis White Beck is the only commentator to recognize the significance of what I am calling motivational effect skepticism. He writes, "Though it displaces the inexplicable mystery of man by only one step, the Critique of Practical Reason [in Chapter III] does attempt at an explanation, in psychological terms, of how the knowledge of the moral law can be effective in the determination of conduct. . . It is essential that this mystery be removed from the phenomenological surface, as it were, for the thing is so puzzling that doubts of its reality can have the actual effect of reducing the effectiveness of this incentive" (Commentary, 2 IO-I I). However, Beck does not say anything beyond this to show how Kant succeeds in removing the mystery. 
732 JOURNAL OF THE HISTORY OF PHILOSOPHY 52:4 OCTOBER 2OI 4

but whether it can have an effect appropriate to motivate action from duty. And this is where we face a skeptical threat, since it looks as though the feelings our recognition of the moral law elicits from us (whether painful or pleasurable) are all of a pathological nature. ${ }^{\mathrm{I2}}$ This is what I am calling the threat of motivational effect skepticism.

Before moving forward, it is important to see that the threat I have just highlighted differs from its classical version-famously voiced by Hume-that reason can never "immediately prevent or produce any action." ${ }^{13}$ Indeed, later in Groundwork III Kant is quite clear that skepticism about the causal efficacy of reason poses no genuine threat. "In order for a sensibly affected rational being to will that for which reason alone prescribes the "ought," he writes, "it is admittedly required that his reason have the capacity to induce a feeling of pleasure or of delight in the fulfillment of duty, and thus there is required a causality of reason to determine sensibility in conformity with its principles" (GMS, AA 4:460). But this is beyond the reach of our understanding. Our knowledge of causality is limited to possible experience (a basic tenet of Kant's critical epistemology). So it is impossible to see, Kant concludes, "how a mere thought which itself contains nothing sensible produces a feeling of pleasure or displeasure" (GMS, AA 4:460).

In saying this, Kant wants to preempt any doubts we might have about the source of moral feeling. If we had to explain this source, from a third-person perspective, it seems we would be defenseless against those who deny reason can produce a motivationally effective feeling in us. But Kant's point is just the reverse. We cannot know the source of moral feeling because it rests on the assumption of a non-natural cause; and for the same reason we cannot claim to know it is impossible. We can then defend the possibility of moral motivation against those who presume to have deeper insight than we do into the powers of practical reason (GMS, AA 4:459). Of course, this is only a sketch of Kant's rather complex position in Groundwork III, but it suffices for our purposes here. ${ }^{\mathrm{I} 4}$ All I have wanted to highlight is that skepticism about the cause of moral feeling is unfounded, for Kant, because it oversteps the limits of human understanding. However, a different kind of skepticism surfaces when we consider the effects our recognition of the moral law has on us, for then one can ask how any of these effects are suited to

${ }^{12}$ This will not be a problem for those who deny the feeling of respect plays a positive role in moral motivation; but this raises a larger interpretive issue I am saving for $\S 5$.

${ }^{13}$ Hume, Treatise, 3.I.I. Christine Korsgaard also discusses this kind of skepticism in connection with Kant and Bernard Williams; see her "Skepticism about Practical Reason."

${ }^{14}$ It is worth bearing in mind that Kant's central aim in the Groundwork is to clarify the principle of morality and establish its authority as a categorical imperative. Within this context it is not necessary to work out all the subtleties of a critique of practical reason, including the question of how reason can be practical for sensible beings like ourselves. So understood, the task Kant assigns to the footnote from GMS, AA 4:40I is straightforward. He is speaking not so much to a critic who demands a fuller account of the feeling of respect, owing to the question of whether respect is suited to the role of moral motivation. Rather, he is speaking to someone who is liable to assume that feelings are not only obscure but also in every case "received by means of influence" and so tied to inclination or fear. In this way Kant's treatment of moral feeling in the Groundwork, while brief, serves its role for the book. I am grateful to an anonymous reviewer for helping me clarify this. 
motivate action from duty. Having this new skeptical threat in view, we are ready to turn to the second Critique-my central text in this paper-where we find an entire chapter devoted to the topics of moral sensibility and moral motivation.

\section{MORAL FEELING IN THE SECOND CRITIQUE}

\section{I. Kant's Definition of Feeling}

In the Preface to the second Critique, after dismissing the critical reviews of the Groundwork, Kant says, "[A] further objection could have been raised" (KpV, AA 5:9n). ${ }^{\text {I5 }}$ Here, in a footnote, he tells us one could have criticized the Groundwork for not defining the concept of pleasure. In response, Kant says that pleasure is the "representation of agreement of an object or of an action with the subjective conditions of life" (KpV, AA 5:9n). ${ }^{16}$ According to this definition, ${ }^{17}$ every feeling has an intentional object (perceived by the senses, or imagined in thought) as well as an accompanying representation of the object's agreeableness or disagreeableness to the subject. ${ }^{18}$ This makes every feeling reflexive in character: "pleasure" is the representation of agreeableness-to-oneself; "pain," the representation of disagreeableness-to-oneself. Notice, however, that nothing in this definition says that what we find agreeable or disagreeable must pertain to our sensible inclinations. "It is easily seen," Kant writes, "that the question whether pleasure must always be put at the basis of the faculty of desire or whether under certain conditions pleasure only follows upon its determination, is left undecided from this exposition" ( $K p V$, AA 5:9n).

${ }^{15}$ In the third Critique, Kant says explicitly that respect is the only feeling of which we have a priori cognition. "To be sure," he explains, "in the Critique of Practical Reason we actually derived the feeling of respect (as a special and peculiar modification of this feeling, which will not coincide exactly either with the pleasure or with the displeasure that we obtain from empirical objects) from the universal moral concepts a priori. But there we could also step beyond the bounds of experience and appeal to a causality that rests on a supersensible property of the subject, namely that of freedom" ( $K U$, AA 5:222). I will follow this clue in my reading of the second Critique to follow.

${ }^{16}$ The complaint would be "unfair," Kant thinks, because his account of these concepts in psychology "could be reasonably presupposed." Presumably Kant is referring to the chapter on psychology offered in his Lectures on Metaphysics. See, for example, Metaphysik Mrongovious (LM, AA 29:89I); Metaphysik $L_{1}$ ( $L M$, AA 28:246); Metaphysik $L_{2}$ ( $L M$, AA 28:586); Vigilantius $K_{3}$ ( $L M$, AA 29:IOI3). See also Wuerth ("Sense and Sensibility," I 58 ) for further discussion of the footnote from KpV, AA 5:9.

${ }^{17}$ Kant calls it a "transcendental definition" in the first Introduction to the third Critique (I790). He writes, "It is useful to attempt a transcendental definition of concepts which are used as empirical principles, if one has cause to suspect that they have kinship with the pure faculty of cognition a priori. One then proceeds like the mathematician, who makes it much easier to solve his problem by leaving its empirical data undetermined and bringing the mere synthesis of them under the expressions of pure arithmetic" ( $K U, \mathrm{AA} 20: 230$ ). He also says we can think of empirical concepts in this way if we recognize their "kinship" or "affinity" with reason (cf. KU, AA 5:I77n). See also Kant's marginal note on transcendental definitions (at A538/B566) in his personal copy of the first Critique (pages 535-36 in the Guyer/Wood translation).

${ }^{18}$ This claim is not unique to the second Critique. Consider the following notes recorded by Kant's students in the I770s: "But what is a feeling? That is something hard to determine. We sense ourselves. ... The subjective representation of the entire power of life for receiving or excluding objects is the relation of satisfaction or dissatisfaction. Thus feeling is the relation of objects not to the representation, but rather to the entire power of the mind.... Feeling consists in the relation of a representation not to the object, but to the entire subject. Pleasure and displeasure are not cognitions at all" ( $L M, \mathrm{AA}$ 28:586; 28:247). For an excellent discussion of pre-Kantian views of feeling, see Thiel, "Inner Sense." 
To use a simple example, suppose I enjoy the taste of wine. If this is the case, my representation of it will be agreeable. When I determine myself by this representation, seeking its object, I will then have a desire: namely, to drink the wine. On one level, the wine must be an object of possible experience, which is to say I must perceive the substance or represent it in thought; but my feeling of pleasure for it is subjective. This is why the capacity to feel is not like sensibility in general, namely, to receive sensory impressions outside of me. ${ }^{\text {I9 }}$ Kant emphasizes this when he says that sensibility in the domain of practical reason "is not regarded as a capacity for intuition at all but only as feeling (which can be a subjective ground of desire)" ( $K p V$, AA 5:90). A feeling of agreeableness, whether before a glass of wine or before the moral law, concerns me-how I relate to an object or action-not anything outside of me.

Since this definition of feeling is implicit in the analysis of respect from the Groundwork, Kant is right to say it would be "unfair" to accuse him for not defining pleasure or related concepts ( $\left.K p V, \mathrm{AA}_{5}: 9 \mathrm{n}\right)$. But we should not be misled by this remark. The definition of feeling from the Preface of the second Critique allows Kant to approach the question of moral feeling from an entirely different point of view. To see this, consider what he says at the beginning of Chapter III:

$[\mathrm{N}]$ othing further remains than to determine carefully in what way the moral law becomes the incentive and, inasmuch as it is, what happens to the human faculty of desire as an effect of that determining ground upon it.... What we shall have to show a priori is, therefore, not the ground from which the moral law in itself supplies an incentive but rather what it effects (or, to put it better, must effect) in the mind insofar as it is an incentive. ( $K p V$, AA 5:72; my emphasis) ${ }^{20}$

At first glance this passage may seem to conflict with Kant's claim from Groundwork III: that we cannot comprehend "how a mere thought which itself contains nothing sensible produces a feeling of pleasure or displeasure" (GMS, AA 4:460). Yet on closer inspection we can see that Kant is bracketing the question of reason's causal efficacy, from a third-person perspective, focusing instead on the question of what the moral law must feel like, from a first-person perspective. Moreover, Kant is saying that within the space this new question makes available to us, we can see how our consciousness of the moral law must influence sensibility, our capacity to feel pleasure and pain. This does not give us insight into the ground of moral feeling (which Kant says is unknowable), but it does make room for a kind of phenomenology of moral feeling, a phenomenology that is a priori in a sense I will clarify below. ${ }^{21}$

${ }^{19}$ As Kant puts it, "The pleasant taste of a wine does not belong to the objective determinations of the wine, thus of an object even considered as an appearance, but rather to the particular constitution of sense in the subject that enjoys it" (A28).

${ }^{2}$ In Chapter III Kant uses the term 'a priori' in the old-fashioned sense of 'in advance of' particular empirical experiences. So defined, his aim is to see the effects our recognition of the moral law must have on our capacity to feel, irrespective of anyone's particular psychological constitution. This is important for understanding the status of Kant's moral phenomenology, as I will discuss below (in $\$ 4.2$ ).

${ }^{21}$ As we shall see, focusing on this aspect of Chapter III opens up a framework of explanation missing from the debate between intellectualist and affectivist readings of Kant. 


\subsection{Self-Love and Self-Conceit}

To start off, we know from the Groundwork that the moral law sets a normative limit on doing what we please, and that is why our consciousness of it must be painful. Kant repeats this point in the second Critique, but now he makes a further distinction that is very important for us here. He says our recognition of the moral law not only infringes upon self-love but also "strikes down" our self-conceit. The latter effect is also like pain, but it does not have a sensible source. When our self-conceit is struck down, the experience we have is one of "humiliation" (Demütigung). For clarification, I will speak of the pain of self-love ("pain sl”) and the pain of self-conceit ("pain ${ }_{\mathrm{sc}}$ ").

One immediate difficulty is that Kant does not say what he means by 'selfconceit' (Eigendünkel), or why it is a propensity. Fortunately, we can provide these missing details with the benefit of hindsight. In his Religion Within the Boundaries of Mere Reason (I793), Kant defines a 'propensity' as the "subjective ground of the possibility of an inclination (habitual desire, concupiscentia)" (RGV, AA 6:28; cf. MS, AA 6:2I2; Anth, AA 7:25I). The Latin gloss indicates he is following a broadly Scholastic theory according to which concupiscentia is the capacity of a sinful desire-as when Augustine speaks of people who have a "weakness for wine" (cf. $R G V$, AA 6:28n). Of course, Kant is not speaking of self-conceit in the colloquial sense, as a character trait certain individuals display, like arrogance or pride. Rather, he thinks of it as a tendency of choice all rational human beings possess. The point of the Latin gloss, I take it, is that self-conceit is a "propensity" in the sense that we author it prior to any physical deed, in the same way that one's susceptibility to alcohol precedes one's addiction to it. ${ }^{22}$

This is somewhat confusing, however. Kant maintains that self-conceit is rooted in our power of rational choice, but he also says that what it aspires to is irrational, all things considered. In self-conceit we confer value onto the inclinations in such a way that the demands of our sensible nature appear to have the authority of law. As Kant puts it, "[I]f self-love makes itself lawgiving and the unconditional practical principle, it can be called self-conceit" (KpV, AA 5:74). In this way selfconceit involves an illegitimate promotion of self-love, our natural tendency to care for the inclinations, to a position of first rank in the will. But this brings us to ask: Why, for Kant, do we have a tendency to do this? Why do we freely orient our power of choice in a way that makes sensibility lawgiving?

To answer this question, let us take a brief detour to the first Critique, where Kant describes the kind of sophistical inferences underlying traditional metaphysics. ${ }^{23}$

${ }^{22}$ Kant repeats this point in the Metaphysics of Morals: "Concupiscence (lusting after something) must also be distinguished from desire itself, as a stimulus to determining desire. Concupiscence is always a sensible modification of the mind but one that has not yet become an act of the faculty of desire" (MS, AA 6:2I3). For more on Kant's idea of a propensity, see Frierson, "Kant's Empirical Account of Action," $2 \mathrm{I}$.

${ }^{23}$ The general error of traditional metaphysics, in Kant's estimation, is to mistake the subjective condition of reason's use, its maxim for seeking the complete series of conditions for any given conditioned, with a principle for determining a given, unconditioned object. He writes, "[In] our reason (considered subjectively as a human faculty of cognition) there lie fundamental rules and maxims for its use, which look entirely like objective principles, and through them it comes about that the subjective necessity of a certain connection of our concepts on behalf of the understanding is taken for an 
The errors of rational psychology, to take a paradigm case, all rest on a "natural and unavoidable" illusion that attaches to the unity of self-consciousness. Though the unity is a formal condition of thinking, and so contains nothing more than the possibility of ascribing mental states to ourselves, Kant says it appears to us as something real. The rational psychologist-as someone who already accepts appearances for things-in-themselves-infers the ontological predicates of substantiality, simplicity, etc., from the unity found in the expression 'I think.' $\mathrm{He}$ effectively confuses the subjective conditions of thought for objective conditions of the soul.

The error lies in the inference, but Kant thinks we are susceptible to the inference because of an underlying "illusion"-in this case, the illusion of objectivity that arises from the thinking self. ${ }^{24}$ It is like the way an optical illusion appears to us, for example, when the moon appears to expand the closer it approaches the horizon (A279/B 354). In the case of rational psychology, we think we have knowledge of ourselves as noumenal subjects, when in truth we only have awareness of the possible "I think" attending our mental states. Transcendental illusions are like optical illusions, Kant explains, because they do not diminish when we apprehend their non-reality. Rather strikingly, their non-reality is perspectival, a product of the subjective viewpoint we have in relation to ourselves and the world around us.

I have argued elsewhere that a similar sort of illusion is at the basis of selfconceit. ${ }^{25}$ On this line of interpretation, we are prone to mistake a maxim of satisfying the inclinations for an unconditional principle of the will. Our subsequent "act" of conferring authority onto sensibility is tempting, and naturally so, because it rests on an illusion that arises from the perspective we have as rational beings with needs and inclinations. We think the claims of our sensible nature should have priority in deliberation because they are the first in time to make demands on us, and they make demands on us repeatedly (we always have desires, even after developing our rational capacities). Consequently, we are liable to think that pursuing "happiness" (Glückseligkeit), the sum-total satisfaction of our desires, should take priority in all matters of choice (cf. KpV, AA 5:25, 5:73; GMS, AA 4:399). To use a spatial metaphor, we might say the idea of our happiness appears large in our deliberative outlook, and we are prone to confuse this largeness for its authority. ${ }^{26}$

\footnotetext{
objective necessity, the determination of things in themselves... [This is] an illusion that cannot be avoided at all ... just as little as the astronomer can prevent the rising moon from appearing larger to him, even when he is not deceived by this illusion" (A279/B 354$)$.

${ }^{24} \mathrm{My}$ account of transcendental illusion is indebted to Grier, Transcendental Illusion; and Allison, Transcendental Idealism.

${ }^{25}$ I develop this claim at length in my paper "Self-Conceit."

${ }^{26}$ The genesis of self-conceit is actually more complicated than this, but I am only providing an abbreviated version of the reconstruction I have defended in "Self-Conceit." As I argue in that paper, the demandingness of our sensible inclinations forces us to imagine our happiness, as the sum-total satisfaction of our inclinations, and that in turn places us under a maxim to pursue our happiness. Strictly speaking, then, the "illusion" at the basis of self-conceit comes from reason-from the maxim to pursue happiness-which we mistakenly identify as an unconditional law.
} 
Kant makes a similar point in the second Critique, writing that

we find our nature as sensible beings so constituted that the matter of the faculty of desire (objects of inclination, whether of hope or fear) first forces itself upon us, and we find our pathologically determinable self, even though it is quite unfit to give universal law through its maxims, nevertheless striving antecedently to make its claims primary and originally valid, just as if it constituted our entire self. ( $K p V$, AA 5:74)

To be clear, satisfying our needs and inclinations is not a source of error. Kant thinks this type of self-love can function as a valid maxim of choice because it requires nothing more than a basic fulfillment of our wants and wishes. Yet there is a deeper error at work in self-conceit, one I am suggesting is like the error of rational psychology (i.e. inferring objective knowledge of the soul from merely subjective conditions of thought). In comparing the two, we can say that in selfconceit we turn a subjective maxim for following our "pathologically determinable self" into an objective law whose demands would be, by definition, absolute and beyond question.

While much more could be said about the parallels I am sketching, we have enough material to understand Kant's key moves in Chapter III. To sum up, I have claimed that by calling self-conceit a propensity, Kant is saying it is present prior to any specific deed. As a propensity rooted in our power of rational choice, self-conceit orients the will by making sensibility a source of law. Comparing this account to Kant's critique of rational psychology, I have also suggested we can understand the origin of self-conceit in terms of an illusion that is part of the perspective we have as rational beings with needs and inclinations. This last point explains why self-conceit involves an exercise of free choice-and so is something we are responsible for-even though it rests on an illusion natural to beings like ourselves.

\section{H U M I L I A T I O N A N D S E L F-R E S P E C T}

\section{I. The Sublimity of Rational Nature}

Let us now see how this relates to Kant's account of moral sensibility in the second Critique. First of all, it is clear why our awareness of authorship in self-conceit must produce a negative feeling when we compare ourselves to the moral law. This is the feeling Kant calls "humiliation." Building from the previous section, we can say that in comparing ourselves to the moral law, we must see through the illusion our selfconceit is based on, namely, the misperceived value of our needs and inclinations. Recognizing the moral law must be humbling, therefore, because we are forced to acknowledge the emptiness of our claim to make sensibility lawgiving. ${ }^{27}$

Kant's battle metaphor is somewhat misleading, however. As I see things, our self-conceit is not so much struck down as it is painfully enlightened. Our self-conceit

${ }^{27}$ As Kant writes, pure practical reason "strikes down self-conceit altogether, since all claims to esteem for oneself that precede accord with the moral law are null and quite unwarranted because certainty of a disposition in accord with this law is the first condition of any worth of a person ... and any presumption prior to this is false and opposed to the law. Now, the propensity to self-esteem, so long as it rests only on sensibility, belongs with the inclinations which the moral law infringes upon. So the moral law strikes down self-conceit" (KpV, AA 5:73). 
738 JOURNAL OF THE HISTORY OF PHILOSOPHY 5 2:4 OCTOBER 2OI 4

is based on the misperceived value of our needs and inclinations, and we must feel something like pain when this conception of ourselves is stripped from us. When we see through the pretense of our self-conceit (our act of making the claims of desire "primary and originally valid"), we must recognize our mistake in having dignified those claims. Yet— to repeat my point above-this feeling is different from that of infringement, and if our ego suffers a blow here it is only because we cast reproach on ourselves. The pain of humiliation is not a feeling of hindrance from doing what we please; it is a feeling of reproach, reproach for what we have already done. That is why we must distinguish the two negative effects our recognition of the moral law has on us: pain $_{\mathrm{sl}}$ is not the same as pain ${ }_{\mathrm{sc}}$.

By considering the illusion self-conceit is based on, it is clear why humiliation is different from a feeling of infringement. Yet to account for the motivating effect reason must have on sensibility, I think we need to re-introduce the spatial metaphor outlined above. The inclinations call for our attention, I have argued, because of the frequency with which they place demands on us. This in turn places us under a maxim to seek our happiness, the sum-total satisfaction of our desires. We are then prone to mistake the authority of this maxim for an unconditional principle, as if seeking happiness should take priority in all matters of deliberation-an illusion I have suggested is similar to what we face in rational speculation. Having discussed Kant's account of humiliation, we can now see why the awareness of our authorship in self-conceit must elicit a positive feeling in us as well. In criticizing our tendency to overvalue the pursuit of happiness, we must also be aware of our capacity to act independently of pathological incentives, and this discovery must elicit a kind of pleasure in us. Call this the pleasure of selfrespect ("pleasure ${ }_{\text {sr }}$ )..$^{28}$

Reviewing the points I have covered so far, we can say that the value we recognize in our rational nature is greater than that of our inclinations. In this comparison, the pursuit of happiness-once so large in our deliberative outlook-now appears small. ${ }^{29}$ If this is right, then we can appreciate why Kant later relates the feeling of self-respect to a feeling of the sublime, for the sublime is that against which everything else seems small ( $K U$, AA 5:250). As he writes, "The majesty of the law instills awe (not dread, which repels; and also not fascination which invites familiarity); and this awe rouses the respect of the subject toward his master, except that in this case, since the master lies in us, it rouses a feeling of the sublimity of our

${ }^{28}$ In contemporary discussions of the topic, self-respect often means a healthy form of self-esteem or proper pride in oneself. My use of the term runs deeper than this; it is closer to what Darwall calls "recognition self-respect," the awareness we have of ourselves as beings with dignity ("Two Kinds of Respect"). I take my discussion to be broadly consistent with the literature on this topic. See Massey, "Kant on Self-Respect"; Dillon, "Respect"; and Stark, "Rationality of Valuing Oneself."

${ }^{29}$ Allison makes a similar point: "Kant's basic claim is that the constraint or limitation of our sensuous nature and its pretensions, which supposedly results from the awareness of the authoritativeness of the moral law, is at the same time an elevation (Erhebung) of our rational nature and produces a feeling of self-approbation that is the positive counterpart of the negative feelings of pain and humiliation. As Kant makes clear, this is because the constraint is self-imposed, that is, imposed by one's own legislative reason" (Freedom, I25). I agree that the "unmasking" of self-conceit, and the humiliating feeling that follows from it, must result from our awareness of the moral law's authoritativeness. But Allison does not explain how a humiliating feeling connects to the uplifting discovery of our rational nature. 
own vocation and enraptures us more than any beauty" ( $R G V$, AA 6:23n)..$^{\circ}$ It may be this feeling, a feeling for the sublimity of our rational nature, which constitutes our interest to adopt the moral law as our own maxim of choice (a point I will return to shortly). ${ }^{3}$

As we can see, if we did not confer authority onto the pursuit of happiness in self-conceit, we would not be in a position to criticize ourselves before the moral law. Nor would we be in a position to recognize a different source of value within ourselves. The lowering and uplifting moments of respect are internally connected, therefore, because they have the same object. ${ }^{32}$ Our free conferral of authority to the inclinations is the object of our humiliation, but this freedom to confer authority is also the object of our elevation. Here there is no room for motivational effect skepticism, because the pleasure ${ }_{\mathrm{sr}}$ we feel in respecting ourselves arises from the same awareness that underlies the pain ${ }_{\mathrm{sc}}$ brought about by our self-criticism. It is the awareness of ourselves as rational beings. With pleasure ${ }_{\mathrm{sr}}$, then, we at last have an effect on sensibility that is suited to play the role of moral motivation, for this feeling arises from an awareness of our autonomy. ${ }^{33}$

\subsection{Our "Higher Vocation"}

Later in Chapter III Kant connects the feeling of self-respect to the discovery of our autonomy in moral constraint. As he writes, "[S] ince this constraint is exercised only by the lawgiving of the agent's own reason, it also contains something elevating [Erhebung], and the subjective effect on feeling, inasmuch as pure practical reason is the sole cause of it, can thus be called self-approbation [Selbstbilligung] with reference to pure practical reason" ( $K p V$, AA 5:80-8 I; modified). Kant then links this subjective effect to a pure moral interest: the agent "now becomes conscious of an altogether different interest subjectively produced by the law, which is purely practical and free" (KpV, AA 5:80-8I).

Considering Kant's claim that an interest is always based on an incentive ( $K p V$, AA 5:80), it follows from the logic of his analysis that the awareness of ourselves as rational beings must have an effect on us like pleasure-what Kant now terms "self-approbation" and what I am calling "pleasure sr $^{2}$ and that this effect is the basis of our interest to make the law our highest maxim of choice. Kant returns to this point in speaking of the "constitution" of the moral incentive. "This incentive,"

${ }^{3}$ Herman aptly describes our initial encounter with the moral law as bringing about a "shock of self-recognition." She writes, "We see that what we had taken to be first in the order of value-our satisfaction-is not. We are also revealed to ourselves to be persons of moral standing or dignity: our own rational nature as a source of value that has authority over all action and choice" (Moral Literacy, I96). Bagnoli makes a similar point about the feeling of humiliation ("Emotions and Categorical Authority," I73-74).

${ }^{3}$ For discussion of the similarities between the feeling of respect and the sublime, see Nahm, "Sublimity and the Moral Law"; Walker, "Achtung in the Grundlegung"; and Clewis, Kantian Sublime.

${ }^{32}$ Although we arrive at this conclusion from different routes, my account is similar to Engstrom's, especially when he speaks of "the felt diminution of self-conceit . . . and the corresponding felt magnification of the moral law" ("Triebfeder," I I 7 ).

${ }^{33}$ Speaking of 'awareness' is somewhat misleading. Yet we should bear in mind that, while every feeling has a relation to the subject, that relation is not one of cognition, strictly speaking. This is important for Kant's account, given that feelings, unlike cognitions, are capable of motivating us by connecting to our faculty of desire. Thanks to Kristin Gjesdal for prompting me to clarify this. 
he writes, "is none other than the pure moral law itself insofar as this law allows us to discern the sublimity of our own supersensible existence and subjectively brings about, in human beings, respect for their higher vocation" ( $K p V$, AA $5: 88$ ). To fill in the details of this remark, we can say that our recognition of the moral law is elevating because it lets us see the connection of our rational nature to a "higher vocation" (höhere Bestimmung) relative to the end we had assigned to ourselves in self-conceit. ${ }^{34}$ This is why the spatial metaphor is fitting after all. In feeling respect for ourselves, we come to see that the value of our happiness is infinitely small in comparison to the value of our rational nature. ${ }^{35}$

At this juncture, however, one might raise the following objection. ${ }^{36}$ It seems difficult to recall a moment in which we have felt ourselves humiliated by the moral law or uplifted by the discovery of our rational nature. It seems especially difficult to recall a moment in which we have seen through the "illusion" of self-conceit and recognized in our rational nature an infinitely greater source of value. How accurate, then, is Kant's moral phenomenology? In reply, we should bear in mind that Kant's aim in Chapter III is not to present any kind of descriptive analysis. That is, he is not trying to make empirical generalizations based on what moral experience is like for certain people, under certain conditions. Instead, Kant is concerned with what moral experience must be like for every rational being with the capacity to feel, regardless of his or her particular sensibility. In this way his focus on the first-personal perspective is suitably idealized, enough to make the phenomenology of Chapter III a priori, as I said earlier (cf. KpV, AA 5:72).37

Even with this qualification in place, worries about the accuracy of Kant's phenomenology are not unfounded. For if Kant's account is successful, we should expect to see the humiliating-elevating aspects of moral feeling reflected in more specific, everyday cases. Settling this issue would take me beyond the scope of this paper, but it is worth noting that Kant supplies material for a reply later in the second Critique. One passage worth considering more closely occurs near the end of Part II where Kant connects the humiliating-elevating aspects of moral feeling to the phenomenology of confession. What is telling is that he relates this experience to the adoption of a standpoint that is initially painful yet subsequently exalting:

In a case where I alone know that the wrong is on my side-although a free confession of it and an offer of satisfaction are strongly opposed by vanity, selfishness, and even an otherwise not illegitimate antipathy to him whose right I have detracted from-I am nevertheless able to disregard all these considerations; and this includes consciousness

${ }^{34} \mathrm{On}$ this point my reading adds to Korsgaard's, who also argues that our higher vocation constitutes an incentive to lead a life guided by the moral law; see her Kingdom of Ends, I 76.

${ }^{35}$ Reath notes that the metaphor of mechanical force is "consistently embedded in discussions in which the dominant theme is a struggle for authority, sovereignty, superiority, and so on, in which it is claims or pretensions that are being opposed to each other." Here I agree with Reath: "a close reading of this chapter of the second Critique shows that legal and political metaphors dominate" (Agency and Autonomy, 3on 26).

${ }^{36}$ I would like to thank John Dyck and Chris Herrera for pressing me on this point.

${ }^{37} \mathrm{Kant}$ is not providing a moral phenomenology in the (mostly deflationary) sense used today. There are, however, similarities worth exploring. See Mandelbaum, Phenomenology of Moral Experience; Horgan and Timmons, "Moral Phenomenology and Moral Theory," "Moral Phenomenology and Moral Objectivity"; and Gill, "Variability," "Moral Phenomenology in Hutcheson and Hume." 
of an independence from inclinations, from circumstances, and of the possibility of being sufficient to myself, which is salutary to me in general and in other respects as well. And now the law of duty, through the positive worth that observance of it lets us feel, finds readier access through the respect for ourselves in the consciousness of our freedom. (KpV, AA 5:I6I; modified)

An act of confession must be humbling insofar as we face our wrongdoing and own up to the harm we have caused another person. Granted, not every case of confession will be as elevating as Kant describes here. But insofar as we recognize that it is the better part of ourselves that demands the confession in the first place, it is reasonable to suppose that our humility will change into esteem for ourselves. And if that is all Kant means when he says the moral law finds "readier admittance" to sensibility, then it is also reasonable to suppose that our incentive to act in compliance with the moral law will manifest itself as a form of self-respect. Humiliation must give way to self-respect, then, when we recognize that the demand to confess-to expose our wrongdoing-is one we freely impose upon ourselves.

\section{THE I N T ERPRET IVE D IS P U T E}

A growing number of scholars have recently argued that respect is like a feeling in a very real sense: it has affective force, and that force is variable in degree of intensity. Richard McCarty is the main proponent of this reading, the affectivist view, and like others he opposes a reading of Kant that explains moral motivation in strictly cognitive terms, the intellectualist view. ${ }^{38}$ The dispute centers, as McCarty notes, on the question of "whether the affective component of respect plays any role in the mechanism of moral motivation" ("Kantian Moral Motivation," 430). As he writes,

Intellectualists hold that respect for the moral law is, or arises from, a purely intellectual recognition of the supreme authority of the moral law, and that this intellectual recognition is sufficient to generate moral action independently of any special motivating feelings or affections. Opposed to the intellectualist interpretation is what I shall call the affectivist view. Affectivists need not deny that Kantian moral motivation initially arises from an intellectual recognition of the moral law. Contrary to intellectualists, however, they maintain that it also depends on a peculiar moral feeling of respect for law, one consequent to the initial recognition or moral judgment the intellectualists emphasize exclusively. ("Kantian Moral Motivation," 42I)

McCarty thus disagrees with Andrews Reath's view that moral feeling plays no motivational role in Kant's account. According to Reath, "[I]t is the practical aspect [of respect] that is active in motivating moral conduct, while the affective side, or feeling of respect, is its effect on certain sensible tendencies" (Agency and Autonomy, IO).

To start with, I agree with McCarty that the intellectualist view faces a number of difficulties. One is that Chapter III of the second Critique contains many passages

${ }^{3}$ For those who land more clearly on the side of affectivism, see Herrera, "Moral Triebfeder"; Grenberg, "Kant's Theory of Action," "Reason and Sensibility"; Guyer, Freedom, Law, and Happiness, Kant's Response to Hume, "Moral Feeling"; Ameriks, "Problem of Moral Motivation"; Zinkin, "Dynamical Terms"; Morrisson, Pleasure in Moral Action; Engstrom, "Triebfeder." Reath is the most forceful proponent of intellectualism (Agency and Autonomy), although a version of the view is found in Allison, Freedom. 
742 JOURNAL OF THE HISTORY OF PHILOSOPHY 5 2:4 OCTOBER 2OI 4

that suggest the feeling-aspect of respect is necessary to motivate moral conduct. Consider the following:

Thus the moral law, since it is a formal determining ground of action through practical pure reason ... is also a subjective determining ground-that is, an incentive-to this action inasmuch as it has influence on the sensibility of the subject and effects a feeling conducive to the influence of the law upon the will. (KpV, AA 5:75; my emphasis)

$[R]$ espect for the moral law must be regarded as also a positive though indirect effect of the moral law on feeling insofar as the law weakens the hindering influence of the inclinations by humiliating self-conceit, and must therefore be regarded as a subjective ground of activity — that is, as the incentive to compliance with the law-and as the ground for maxims of a course of life in conformity with it. ( $\mathrm{KpV}$, AA 5:79).

Now if our recognition of the moral law's authority is necessary and sufficient to move us, why would Kant speak of reason's "influence on the sensibility of the subject" as effecting "a feeling conducive to the influence of the law upon the will"? As far as I can tell, it is difficult to make sense of this if we keep to an intellectualist view.

A second difficulty for Reath's interpretation is that it does not fit neatly into the structure of Kant's argument from the second Critique. By Chapter III Kant is already assuming the moral law "determines the will objectively and immediately in the judgment of reason" as part of our ordinary consciousness of the moral law's authority. The question of how reason interacts with sensibility is a question of how this objective determination can also function as an incentive for beings like us. Lastly, a further difficulty worth mentioning is that Reath's interpretation only attends to the negative aspects of moral feeling, either the pain of having our self-love limited ("pain ${ }_{\text {sl }}$ ) or the humiliation of having our self-conceit struck down ("pain sc"). Yet this ignores Kant's effort to connect self-conceit's humiliation to a positive feeling, what I have called pleasure ${ }_{\mathrm{sr}}$.

The affectivist view defended by McCarty suffers from its own shortcomings. Whereas Reath is unable to explain reason's positive effect on sensibility due to the priority he assigns to our intellectual recognition of the moral law, McCarty is unable to explain this effect because he views moral motivation strictly under a "battle of forces" model. The problem with this model is not that it contradicts our freedom of will (a point intellectualist commentators often make ${ }^{39}$ ), but that it only considers the question of moral motivation from a third-person perspective. As I have shown, Kant thinks there is little we can say from this perspective, for there is little we can say about causal relations beyond the sphere of possible experience. So in my understanding, neither the intellectualist nor the affectivist views give us the resources we need to understand Kant's unique kind of phenomenology in the second Critique.

One might wonder where I stand in this dispute. If the awareness of our rational nature elicits a positive feeling in us, and if this feeling is what motivates us to

${ }^{39}$ For example, see Reath, Agency and Autonomy, I3; and Allison, Freedom, I26. The question of whether a battle of forces model ultimately conflicts with Kant's account of free choice is a much larger topic than I can go into. Frierson, for example, argues for their compatibility ("Kant's Account of Empirical Action"), and I am sympathetic with aspects of his account. 
act in compliance with the moral law, then have I not located the active factor of moral motivation in the affective rather than the cognitive side of respect? I am prepared to say yes, but only with the following qualification in place. Like the affectivist, I deny that our recognition of the moral law is a sufficient condition for moral motivation, and that is why I cannot hold to an intellectualist view in any strict sense. But the point I want to make is that we can deny this without having to limit our account of moral feeling to a mechanical model of competing forces. That is to say, we can affirm that feeling and sensibility have a positive role in Kant's ethics without limiting ourselves to the third-person perspective McCarty and others focus on exclusively. $4^{\circ}$

To sharpen this point of my disagreement, the problem with the traditional affectivist view is that it only considers respect as a feeling with varying strength, but the notion of "strength" does not speak to the experience of moral feeling from the agent's own point of view. The problem Kant is concerned with in the second Critique is not how moral feeling can overpower the inclinations, from a third-person perspective. It is, rather, the problem of how reason can access sensibility in a way suited to moral motivation, thereby serving as an incentive in the place of pathological feelings. The aim of Kant's theory of moral sensibility is to show how our recognition of the moral law must influence us, with the positive influence serving as our interest to make the law our own maxim of choice. If we are to understand any of this, we need a suitably idealized phenomenology, rather than a model of competing forces. For however valid this model is, only a first-personal perspective can give us access to the structure of moral motivation, the inner link between moral pain sc $_{\text {and }}$ pleasure sr. $_{\text {. }}$.

\section{O N C L U S I O N}

In this paper, I have sought to defend Kant's theory of moral sensibility from a skeptical threat, what I have called motivational effect skepticism. The threat arises because it is unclear, given Kant's characterization, how reason could have a positive effect on sensibility, one that could motivate us to act from duty. When we understand the distinction Kant draws in the second Critique between self-love and self-conceit, a new interpretive possibility opens up. As I have shown, we must feel humiliated before the moral law when we see our authorship in self-conceit, but we must also feel elevated when we recognize our ability to act independently of pathological incentives. In each case the object of our feeling is our rational

${ }^{40}$ In a more recent work, McCarty shows sensitivity to the phenomenological perspective of Chapter III. He observes that respect is a kind of pleasure that presupposes "a prior, frustrating and therefore painful effect on inclinations." Yet he expresses uncertainty about how these moments relate: "[Respect] can be called moral pleasure, and our feeling it would always presuppose a prior, frustrating and therefore painful effect on inclinations. I think there is more than this in the phenomenology of respect, however. For Kant claimed that the moral law's 'negative effect on feeling (disagreeableness) is pathological' ( $K p V$, AA 5:75). But he also characterized the feeling of respect as not pathological but "practical only'" (Kant's Theory of Action, I79). After this McCarty goes on to suggest that the elevating aspect of respect comes from "at least a vague sense of freedom from the limitations of sensible inclinations" (Kant's Theory of Action, I 80). McCarty, however, presents no solution to the threat of motivational effect skepticism. 
744 JOURNAL OF THE HISTORY OF PHILOSOPHY 52:4 OCTOBER 2OI 4 nature-that is the basis of our humiliation and our elevation. Once we see this, I have argued, the threat of motivational effect skepticism goes away. The problem simply dissolves.

Of course, if someone asks us how reason can exercise causal force, all we can do is affirm our ignorance of such things. And that is Kant's final point in Groundwork III: the skeptic who denies reason can produce a motivationally effective feeling is really speaking about things he cannot know. From a third-person perspective, then, the philosopher's stone will always remain a mystery, since we cannot secure knowledge of causal relations beyond the sphere of possible experience. But when Kant takes up this mystery again in the second Critique, he does so from an entirely different point of view. The approach we find in Chapter III occurs from a perspective that applies to any being with reason and feeling, and from this perspective Kant seeks to analyze the effects morality must have on us. It is no doubt remarkable that in the second Critique we appear to learn something a priori about our sensibility, and so something a priori about ourselves. Whether or not he knew it, this may very well be the philosopher's stone Kant had spent so many years searching for. ${ }^{4 \mathrm{I}}$

\section{A B B R E V I A T I O N S}

In the case of the Critique of Pure Reason, I follow the standard practice of referring to the $\mathrm{I} 78 \mathrm{I}$ (A) and $\mathrm{I} 787$ (B) editions. For all other texts, citations appear in the order of abbreviation, volume number, and page number from the Akademie Ausgabe (AA), Kants Gesammelte Schriften, edited by Königlich Preussische Akademie der Wissenschaften (29 vols. Berlin: de Gruyter, I900-). All translations come from The Cambridge Edition of the Works of Immanuel Kant, edited by Paul Guyer and Allen Wood (Cambridge: Cambridge University Press, I992-). Where I depart from them, I add 'modified' after the in-text citation.

Br Briefe (AA IO-I3), Correspondence. Translated by Arnulf Zweig.

GMS Grundlegung zur Metaphysik der Sitten (AA 4), Groundwork for the Metaphysics of Morals. Translated by Mary Gregor.

GSE Beobachtungen über das Gefühl des Schönen und Erhabenen (AA 2), Observations on the Feeling of the Beautiful and the Sublime. Translated by Paul Guyer.

$D G \quad$ "Prize Essay." Translated by David Walford and Ralf Meerbote.

KpV Kritik der praktischen Vernunft (AA 5), Critique of Practical Reason. Translated by Mary Gregor.

KU Kritik der Urteilskraft (AA 5), Critique of the Power of Judgment. Translated by Paul Guyer and Eric Matthews.

${ }^{4} \mathrm{I}$ have incurred many debts of gratitude while writing this paper. For financial support, I would like to thank the Jackman Humanities Institute for offering me a graduate fellowship and the Social Sciences and Humanities Research Council of Canada for offering me a post-doctoral fellowship. For helpful conversation and feedback on earlier drafts, I would like to thank Don Ainslie, Karl Ameriks, Anthony Bruno, Anne Caughlan, Paul Franks, Kristin Gjesdal, Espen Hammer, Dai Heide, Barbara Herman, Chris Herrera, Karolina Hübner, Karin Nisenbaum, Lara Ostaric, Arthur Ripstein, Ulrich Schlösser, Lisa Shapiro, Sergio Tenenbaum, Evan Tiffany, Leah Ware, David Wolfsdorf, Ariel Zylberman, as well as anonymous reviewers for this journal. I am also grateful for interactions with students in my $20 \mathrm{I} 2$ graduate seminar on Kant's ethics, and audiences at Loyola University Maryland, Temple University, and the University of Toronto. 
MPC Moralphilosophie Collins (AA 27), Moral Philosophy Collins. Translated by Peter Heath.

MSI De mundi sensibilis atque intelligibilis forma et principiis (AA 2), Inaugural Dissertation. Translated by David Walford and Ralf Meerbote.

LM Lectures on Metaphysics (AA 28-29). Translated by Karl Ameriks and Steve Naragon.

NEV "Nachricht von der Einrichtung seiner Vorlesungen in dem Winterhalbenjahre von I765I766" (AA 2), "Announcement." Translated by Chris Bowman and Paul Guyer.

Refl Reflexionen (AA I4-I9), Notes and Fragments. Translated by Chris Bowman, Paul Guyer, and Frederick Rauscher.

RGV Die Religion innerhalb der Grenzen der bloßen Vernunft (AA 6), Religion Within the Boundaries of Mere Reason. Translated by George Di Giovanni.

\section{B I B L I O G R A P H Y}

Allison, Henry. Kant's Theory of Freedom. Cambridge: Cambridge University Press, I990. [Freedom]

Kant's Transcendental Idealism: An Interpretation and Defense. Rev. ed. New Haven, CT: Yale University Press, 2004. [Transcendental Idealism]

Ameriks, Karl. "Kant, Hume, and the Problem of Moral Motivation." In Kant and the Historical Turn: Philosophy as Critical Interpretation, 89-107. Oxford: Clarendon Press, 2004. ["Problem of Moral Motivation"]

Bagnoli, Carla. "Emotions and the Categorical Authority of Moral Reason." In Morality and the Emotions, edited by Carla Bagnoli, 62-8I. Oxford: Oxford University Press, 20I 2. ["Emotions and Categorical Authority"]

Beck, L. W. A Commentary on Kant's Critique of Practical Reason. Chicago: University of Chicago Press, I960. [Commentary]

Broadie, A., and Pybus, E. "Kant's Concept of 'Respect.'” Kant-Studien 66 (I975): 58-64. ["Concept of Respect"]

Clewis, Robert. The Kantian Sublime and the Revelation of Freedom. Cambridge: Cambridge University Press, 2009. [Kantian Sublime]

Darwall, Stephen. "Two Kinds of Respect." Ethics 88 ( I977): 36-49. ["Two Kinds of Respect"]

Dillon, Robin. "Respect: Moral, Emotional, Political." Ethics I07 (I997): 226-49. ["Respect"]

Engstrom, Stephen. "The Triebfeder of Pure Practical Reason." In Kant's Critique of Practical Reason: A Critical Guide, edited by Andrews Reath and Jens Timmermann, 90-I I 8. Cambridge: Cambridge University Press, 2009. ["Triebfeder"]

Frierson, Patrick. "Kant's Empirical Account of Action." Philosophers' Imprint 5 (2005): I-34. ["Kant's Empirical Account of Action"]

Geiger, Ido. "Rational Feelings and Moral Agency." Kantian Review I6 (20I I): 283-308. ["Rational Feelings"]

Gill, Michael. "Variability and Moral Phenomenology." Phenomenology and the Cognitive Sciences 7 (2008): 99-II3. ["Variability"]

"Moral Phenomenology in Hutcheson and Hume." Journal of the History of Philosophy 47 (2009): 569-94. ["Moral Phenomenology in Hutcheson and Hume"]

Grenberg, Jeanine. "Feeling, Desire and Interest in Kant's Theory of Action." Kant-Studien 92 (200I): I 53-79. ["Kant's Theory of Action"]

_. "Making Sense of the Relationship of Reason and Sensibility in Kant's Ethics." Kantian Review I 6 (200I): 46I-72. ["Reason and Sensibility"]

Grier, Michelle. Kant's Doctrine of Transcendental Illusion. Cambridge: Cambridge University Press, 200 I. [Transcendental Illusion]

Guevara, Daniel. Kant's Theory of Moral Motivation. Boulder: Westview Press, 200o. [Moral Motivation]

Guyer, Paul. Kant on Freedom, Law, and Happiness. Cambridge: Cambridge University Press, 2000. [Freedom, Law, and Happiness]

- Knowledge, Reason, and Taste: Kant's Response to Hume. Princeton, NJ: Princeton University Press, 2008. [Kant's Response to Hume]

. "Moral Feeling in the Metaphysics of Morals." In Kant's Metaphysics of Morals: A Critical Guide, edited by Lara Denis, I 30-5 I. Cambridge: Cambridge University Press, 2010. ["Moral Feeling"]

Hegel, G. W. F. Die Phänomenologie des Geistes. Stuttgart: Reclam, 2004. [Phänomenologie]

Henrich, Dieter. "Ethics of Autonomy," translated by L. Hunt. In The Unity of Reason: Essays on Kant's Philosophy, edited by Richard Velkley, 89-I22. Cambridge, MA: Harvard University Press, I996. ["Ethics of Autonomy"] 
746 JOURNAL OF THE HISTORY OF PHILOSOPHY 5 2:4 OCTOBER 2OI 4

Herman, Barbara. Moral Literacy. Cambridge, MA: Harvard University Press, 2007. [Moral Literacy]

_ . "Transforming Incentives: Feelings and the Making of the Kantian Moral Agent." In Philosophical Aspects of the Emotions, edited by Åsa Carlson, I7-44. Stockholm: Thales, 2005. ["Transforming Incentives"]

Herrera, Larry. "Kant on the Moral Triebfeder." Kant-Studien 9I (2000): 395-4IO. ["Moral Triebfeder"]

Horgan, T., and Timmons, M. "Moral Phenomenology and Moral Theory." Philosophical Issues I 5 (2005): 56-77. ["Moral Phenomenology and Moral Theory"]

- "What Does Moral Phenomenology Tell Us About Moral Objectivity?" Social Philosophy and Policy 25 (2008): 267-300. ["Moral Phenomenology and Moral Objectivity"]

Hume, David. A Treatise of Human Nature. 2nd ed. Oxford: Clarendon Press, I978. [Treatise]

Korsgaard, Christine. "Skepticism about Practical Reason." In Creating the Kingdom of Ends, 3 I I-34. Cambridge: Cambridge University Press, I996. ["Skepticism about Practical Reason"]

MacBeath, A. M. "Kant on Moral Feeling." Kant-Studien 74 ( I 973): 283-3 I 4. ["Kant on Moral Feeling"]

Mandelbaum, Maurice. The Phenomenology of Moral Experience. Glencoe, IL: The Free Press, I955. [Phenomenology of Moral Experience]

Massey, Stephen. "Kant on Self-Respect." Journal of the History of Philosophy 2I (I983): 57-73. ["Kant on Self-Respect"]

McCarty, Richard. "Kantian Moral Motivation and the Feeling of Respect." Journal of the History of Philosophy 3 I (I993): 42 I-35. ["Kantian Moral Motivation"]

—. "Motivation and Moral Choice in Kant's Theory of Rational Agency." Kant-Studien 85 (I994): I 5-3 I. ["Kant's Theory of Rational Agency"]

- Kant's Theory of Action. Oxford: Oxford University Press, 2009. [Kant's Theory of Action]

Morrison, Iain. Kant and the Role of Pleasure in Moral Action. Columbus: Ohio University Press, 2008. [Pleasure in Moral Action]

Nahm, M. C. "Sublimity and the Moral Law in Kant's Ethics." Kant-Studien 48 (I957): 502-24. ["Sublimity and the Moral Law"]

Paton, Herbert. The Categorical Imperative: A Study in Kant's Moral Philosophy. London: Hutchinson University Library, 1947. [Categorical Imperative]

Purviance, Susan. "The Apriority of Moral Feeling." Idealistic Studies 22 (I999): 75-87. ["Apriority of Moral Feeling"]

Reath, Andrews. Agency and Autonomy in Kant's Moral Theory. Oxford: Oxford University Press, 2006. [Agency and Autonomy]

. "Kant's Theory of Moral Sensibility: Respect for the Moral Law and the Influence of Inclination." Kant-Studien 80 (I989): 284-302. ["Kant's Theory of Moral Sensibility"]

Reich, Klaus. "Kant and Greek Ethics (Part II)." Mind 48 (I939): 446-63. ["Kant and Greek Ethics"]

Schiller, Friedrich. Kallias oder Über die Schönheit. Über Anmut und Würde. Stuttgart: Reclam, 2006. [Anmut und Würde]

Stark, Cynthia. "The Rationality of Valuing Oneself: A Critique of Kant on Self-Respect." Journal of the History of Philosophy 35 (I998): 65-82. ["Rationality of Valuing Oneself"]

Stratton-Lake, Philip. Kant, Duty, and Moral Worth. London: Routledge, 2000. [Duty and Moral Worth]

Thiel, Udo. "Varieties of Inner Sense: Two Pre-Kantian Theories." Archiv für Geschichte der Philosophie 79 (1997): 58-79. ["Inner Sense"]

Walker, Ralph. "Achtung in the Grundlegung." In Grundlegung zur Metaphysik der Sitten: Ein kooperativer Kommentar. 3rd ed. Edited by Dieter Höffe, 97-I I6. Frankfurt and Main: Vittorio Klostermann, 2000. ["Achtung in the Grundlegung"]

Ware, Owen. "Self-Love and Self-Conceit." Unpublished Manuscript. ["Self-Conceit"]

Wolff, R. P. The Autonomy of Reason: A Commentary on Kant's Groundwork of the Metaphysic of Morals. New York: Harper and Row, 1974. [Autonomy of Reason]

Wood, Allen. Kantian Ethics. Cambridge: Cambridge University Press, 2008. [Kantian Ethics]

. Kant's Ethical Thought. Cambridge: Cambridge University Press, I999. [ Kant's Ethical Thought]

Wuerth, Julian. "Moving Beyond Kant's Account of Agency in the Grounding." In Perfecting Virtue: Essays on Kantian Ethics and Virtue Ethics, edited by Lawrence Jost and Julian Wuerth, I47-63. Cambridge: Cambridge University Press, 20 I I. ["Kant's Account of Agency"]

- "Sense and Sensibility in Kant's Practical Agent: Against the Intellectualism of Korsgaard and Sidgwick." European Journal of Philosophy 2I (20I3): I-36. ["Sense and Sensibility"]

Zinkin, Melissa. "Respect for the Law and the Use of Dynamical Terms in Kant's Theory of Moral Motivation." Archiv für Geschichte der Philosophie 88 (2006): 3 I-53. ["Dynamical Terms"] 